\title{
Not (Just) about the Money: Contextualizing the Labor Activism of College Football Players
}

\author{
Daniel A. Gilbert
}

In recent years, the business of college athletics has become a touchstone issue in U.S. public culture. Growing critical attention to the topic can be attributed in part to the work of civil rights historian Taylor Branch, whose 2011 article in The Atlantic, "The Shame of College Sports," argued that the National Collegiate Athletic Association (NCAA) oversees the exploitation of college athletes. "Two of the noble principles on which the NCAA justifies its existence-'amateurism' and the 'student-athlete' — are cynical hoaxes, legalistic confections propagated by the universities so they can exploit the skills and fame of young athletes." In addition to Branch's piece, the acclaimed 2013 documentary film Schooled, based largely on his analysis, helped to invigorate a national conversation about the economics of college athletics. ${ }^{2}$ Media discussion of the issue has remained rather narrowly focused on questions of dollars and cents - whether college athletes in the so-called revenue-generating sports (men's basketball and football) ought to be paid beyond their current scholarships in light of the vast and increasing amount of revenue their labor generates. Advocates of "pay-for-play" cite figures like the exorbitant salaries that make head coaches the highest-paid public employees in most states and television contracts like ESPN's recent 12-year, \$5.64 billion deal to broadcast college football playoff games. ${ }^{3}$ Defenders of the NCAA amateur model cite the fact that athletes are already compensated in the form of a "free college education," a commodity that, given rising tuition rates, grows increasingly valuable every year. 
It would be a mistake to limit critical scrutiny of the labor politics of collegiate athletics to narrow questions of financial distribution. Such a focus prevents us from observing the ways in which college athletes have become key figures in workplace struggles over the very nature of the university itself. This article examines resonances between college athletes' labor organizing and two broader struggles sweeping America's campuses: the fight against student debt and the Black Lives Matter movement. In what follows, I examine and contextualize two of the most significant instances of collective action by collegiate football players in recent memory: the 2013-14 unionization campaign at Northwestern University and the 2015 threatened strike by players at the University of Missouri. The Northwestern campaign, which culminated in a historic case before the National Labor Relations Board (NLRB) over football players' employee status, was not principally a campaign about demanding radical new forms of compensation. Rather, Northwestern's football players highlighted two deeper dimensions of the university's exploitation of their labor: being saddled with long-term physical liabilities and health-care costs, and having their educational horizons restricted by their athletic obligations. These underreported yet fundamental elements of the Northwestern campaign articulate concerns shared by an entire generation of U.S. college students over the impact of educational debt on their lives and career paths. When framed against the backdrop of the student debt movement, the Northwestern campaign can be seen as one battle in a larger struggle over the value - and values - of U.S. higher education.

Two years after the Northwestern football team's union campaign, their counterparts at the University of Missouri played a critical role in forcing the resignation of campus administrators. The dramatic events in Columbia, Missouri were flashpoints in a historic wave of campus protests. The Missouri struggle, like campaigns led by black students and their allies at more than seventy other campuses across North America, made the university a key site of mobilization in the Black Lives Matter movement. By standing in solidarity with other student activists, the football team helped to demonstrate powerful linkages between the struggles on the streets of cities like Ferguson, Missouri, and calls for racial justice on campuses like their own. Taken together, the bold workplace actions that Northwestern and Missouri football players organized suggest a rethinking of the place of the so-called student-athlete in the modern American university. Debates that remain solely focused on revenue generation and fair compensation fail to ask the most pressing question: what role do athletes have in the fight to redeem American higher education?

\section{The Northwestern Unionization Campaign}

The 2013-14 unionization campaign at Northwestern represented the latest development in a movement for college players' rights that had been growing for decades. One of the movement's central figures, Ramogi Huma, drew 
on his nearly twenty years of organizing experience in helping advance the cause of Northwestern's football players. In 1995, as a freshman linebacker at the University of California at Los Angeles (UCLA), Huma saw his roommate disciplined for accepting an anonymous gift of groceries. This incident was the first in a series of events that Huma came to understand as evidence of structural hypocrisy and mistreatment, leading him to help found a student organization at UCLA dedicated to advocating for athletes' rights. What began as a local effort grew into a national body, and in the years after college, Huma secured the backing of the United Steelworkers of America (USW) and founded a new advocacy organization, the National College Players Association (NCPA). ${ }^{4} \mathrm{Be}-$ ginning with the organization's initial press conference in January 2001, the NCPA became the nation's most prominent organization of college athletes, calling for improved safety measures, health coverage, scholarship funding, and educational opportunities. Among the organization's accomplishments were California's 2012 passage of the Student-Athletes Bill of Rights, an increase in the NCAA's death benefit from $\$ 10,000$ to $\$ 25,000$, and support of the class action litigation brought by former UCLA basketball player Ed O'Bannon over players' rights to proceeds from the commercial use of their names, images, and likenesses. ${ }^{5}$

While football players and other college athletes had been organizing across the country for decades, it was a labor history class that set Northwestern quarterback Kain Colter on the path toward militant action. Colter cites as a turning point his experience in "Field Studies in the Modern Workplace," taught by Nick Dorzweiler (then a Ph.D. candidate in political science, focusing on political theory) in spring 2013 as part of Northwestern's academic internship program. According to Dorzweiler, the class "explores the social and political history of work as an experience in the United States, beginning with the rise of industrial labor in the late nineteenth century and going through to our service-based, white-collar economy of today. The point is to get students to reflect on what working means to them personally, how it affects their development as both human beings and citizens, and why our culture associates certain social and political values with work, but not others. ${ }^{\prime 6}$ Colter was particularly moved by the class's visit to a steel mill. Soon thereafter, he met with other teammates to discuss his growing concerns about their treatment and decided to move forward with action. Colter then contacted Huma, and their initial phone conversation led to an ongoing working relationship. The two men soon began exploring the possibility of organizing Colter's fellow football players at Northwestern. ${ }^{7}$

Conversations and planning continued through the fall, as Colter and other prominent athletes contributed to an evolving and expanding national conversation about exploitation in college sports. On September 21, Colter was one of several college football players from multiple teams to display the slogan \#APU (All Players United) on his uniform, an action coordinated by NCPA members in response to criticism of the O'Bannon case. The \#APU action, 
like every other instance in which college players have taken collective action, elicited criticism from defenders of the status quo. ${ }^{8}$ But the action was also met with a notable level of support and acclaim, including from prominent mainstream sports media figures like ESPN's Michael Wilbon. ${ }^{9}$

While the \#APU action was a one-time event aimed at seizing media attention for the cause of college athletes nationwide, Colter was increasingly convinced that the most effective way to make change was to empower players in their day-to-day working lives on campus. The next step was clear: unionization. With the help of United Steelworkers national political director Tim Waters, Colter and Huma prepared to reach out to the entire team, with the goal of convincing a majority to sign on before university administrators and other opponents could mount an effective anti-union campaign. Their initial goal was to be able to make a public announcement of the team's support for unionization during postseason competition, but the organizers delayed their plans slightly after Northwestern did not qualify for a bowl game. On January 26, 2014, Colter and Huma held a series of meetings with team members, laying out the case for unionization and asking them to sign union authorization cards. Two days later, Colter met with head coach Pat Fitzgerald to inform him that a majority of the team supported the union effort. After meeting with an associate athletic director, Colter joined Huma and USW representatives at a press conference in Chicago to announce their submission of a formal petition to the NLRB for recognition as employees. The press conference also unveiled the formation of a new national labor organization - the College Athletes Players Association (CAPA). Huma informed the press that the struggle at Northwestern would constitute just the first stage in CAPA's campaign to organize all Football Bowl Subdivision players, as well as Division I men's basketball players. ${ }^{10}$

It was significant that as athletes at Northwestern, a private university, Colter and his teammates could press their case as employees under the National Labor Relations Act (NLRA). The makeup of the NLRB - the quasijudicial body that decides cases brought under the NLRA - is determined by presidential appointments, which has meant in recent decades that decisions that expand workers' rights (including those that expand the category of "employee") have been more likely under Democratic presidential administrations. Public universities - including all of Northwestern's competitors in the Big Ten Conference-are governed by state labor laws. As the Northwestern case took shape, Republican lawmakers in Ohio and Michigan moved to explicitly exclude college athletes from employee status. ${ }^{11}$ And, as we will see below, the privatepublic divide within the Big Ten (and the NCAA more broadly) emerged as a central factor in the NLRB's treatment of the Northwestern case.

In announcing the NLRB petition and the founding of CAPA, Colter emphasized that increased compensation was not the group's top priority in pressing for union rights. Rather, Colter insisted, he and his fellow players sought a seat at the bargaining table to address "basic protections that we're not receiving right now," including improved medical coverage. Colter also 
cited the poor graduation rates of basketball and football players and suggested that giving athletes a voice through union recognition would empower them to secure expanded educational opportunities. One of the central proposals that Colter outlined was for an "educational trust fund" that former players would be able to access to complete their degrees. ${ }^{12}$ The NCAA was quick to respond to CAPA's announcement, with a statement from the organization's chief legal officer, Donald Remy: "This union-backed attempt to turn student-athletes into employees undermines the purpose of college: an education. Student-athletes are not employees, and their participation in college sports is voluntary."13

The following month, before the presiding NLRB hearing officer Joyce Hofstra, representatives of CAPA and Northwestern presented their cases. The matter hinged on the issue of employee status - whether Northwestern would be able to convince the NLRB region 13 director Peter Ohr that Colter and his teammates should not be considered university employees. ${ }^{14}$ At the heart of CAPA's case was testimony by Colter, who detailed the day-to-day, yearround labor that he and his teammates performed. One of the university's central counterarguments centered on a precedent drawn from another contested category of campus workers: graduate teaching assistants. Northwestern cited the NLRB's 2004 decision in a case that came out of an organizing drive at Brown University. In Brown, the Bush-era NLRB had ruled that "the overall relationship between the graduate student assistants and Brown is primarily an educational one, rather than an economic one."15 In citing the Brown case, Northwestern's attorneys argued that football players were similarly situated.

On March 26, 2014, Ohr issued a decision favorable to the union, ruling that Northwestern's scholarship football players should be considered employees under the NLRA, and directed that an official election go forward. Ohr rejected the application of Brown, dismissing the notion that Northwestern's scholarship football players were "primarily students." Instead, Ohr declared, "The players spend 50 to 60 hours per week on their football duties during a one-month training camp prior to the start of the academic year and an additional 40 to 50 hours per week on those duties during the three or four month football season. Not only is this more hours than many undisputed full-time employees work at their jobs, it is also more hours than the players spend on their studies." Ohr's decision found that the players "perform services ... for which they receive compensation," and that they labor "under strict and exacting control by their Employer." ${ }^{\prime 16}$ Ohr's decision was a bombshell, its impact tempered only by the fact that it was subject to appeal to the national NLRB. Still, supporters of CAPA's cause greeted the news as a major victory for athletes' rights. ${ }^{17}$ On April 9, Northwestern filed an appeal of Ohr's decision, which the national NLRB subsequently agreed to consider. This meant that when the players participated in an election later that month, their votes were immediately impounded, pending the NLRB's ruling.

As the Northwestern case proceeded from region 13 to the national NLRB, college sports officials moved to enact reforms in response to the growing play- 
ers movement. The most significant outgrowth of this managerial response was an organizational shift adopted by the NCAA granting greater autonomy to the so-called Power Five conferences. This change enabled schools in the Atlantic Coast, Big Ten, Big 12, and Pac 12 and Southeastern Conferences to offer increased scholarship benefits to athletes. ${ }^{18}$ Earlier in 2014, the NCAA had passed new rules governing food, allowing schools to provide unlimited meals and snacks. ${ }^{19}$ Taken together, the new reforms were clear reflections of the growing influence of college athletes' collective organizing. However, the changes implemented represented minor redistributions of resources from rich athletic budgets to athletes and did nothing to alter the fundamental balance of economic power that defined college sports. Just as significantly, players remained without a collective voice in the decision-making process. Only through a union, CAPA supporters insisted, could real change come to the world of bigtime college sports.

In August 2015, the NLRB issued a unanimous decision in the Northwestern case, declining to assert jurisdiction. This ruling, which represented a significant win for university administrators, allowed to Board to decline to take up the fundamental question of whether college athletes are employees. The Board justified the decision by noting that the body only has jurisdiction over private colleges and universities. "As the NCAA and conference maintain substantial control over individual teams, the Board held that asserting jurisdiction over a single team would not promote stability in labor relations across the league." ${ }^{20}$ Speaking to a reporter in the wake of the decision, Colter tried to place the disappointing decision in context of the larger movement he had helped to lead. "It's definitely not a loss," he said. "Since we started this movement, a lot of positive changes have come from this - the introduction of four-year scholarships, increased stipends, maybe better medical coverage, the lifting of food restrictions. A lot of the things that we've been fighting for have been adopted. But there is a lot of room to go."21

One of the accomplishments of the Northwestern movement, despite the loss at the NLRB, was to draw more attention-from commentators, scholars, and activists alike - to athletes as a key category of campus labor. The labor struggles of college athletes had previously remained absent from most accounts of the growing academic labor movement. A representative example is Marc Bousquet's How the University Works: Higher Education and the LowWage Nation, one of the most important studies of academic labor, highlighting the growth of organizing among graduate teachers and nontenure track faculty, in particular. ${ }^{22}$ While Bousquet highlights big-time college sports as an example of the corporatization of the university, he does not examine the employee status of athletes. This observation is not intended to criticize Bousquet or other scholars for omitting athletic labor from their analysis, but rather to highlight the ways in which athletic labor has remained largely invisible in even the most critical studies of universities in the age of corporatization and privatization. This invisibility is the product of a core managerial logic of the contemporary 
U.S. university - the redefinition of growing sectors of campus labor as nonwork, as evidenced in the NLRB case involving Brown's graduate employees that Northwestern attempted to invoke as precedent for football players.

Another accomplishment of the Northwestern unionization attempt has been to help mobilize a growing movement of faculty support for college athletes. Cofounded in March 2015 by faculty members from Drexel University and the University of South Carolina, the College Athletes Rights and Empowerment Faculty Coalition (CARE-FC) has grown into a national organization of professors dedicated to supporting athletes' struggles for a collective voice over the conditions of their work. As CARE-FC's founding press release asserted, "The path to the transformation of college sports rests with the athletes themselves." The organization pledged to work to support the movement in four ways: "developing relationships" with CAPA and other players associations, "educating public policy makers" about exploitation in college sports, drawing public attention to the "disproportionate negative impact that college sport business practices have on college athletes in the racial minority," and opposing so-called reform efforts that "do not result in justice and fairness for athletes." ${ }^{23}$

The NLRB's "punt" on the employee status of Northwestern's football players did nothing to quell the intensifying public debate over the notion that college athletes ought to be compensated for their labor. There remains a pervasive sense among many commentators that scholarship athletes are, in effect, already getting paid for their labor on the field, in the form of a free college education. Athletes and their advocates have pushed back against these claims with economic arguments of their own. In particular, supporters of pay-for-play point out that the tuition reimbursements and small stipends to cover living expenses that athletes receive are insignificant when placed against the backdrop of the soaring profits reaped by the college sports industry. Furthermore, despite recent reforms by the Power Five conferences, most athletic scholarships are not guaranteed, meaning that players who suffer major injuries face the choice of leaving college or taking on enormous debt to remain in school.

Thanks in large part to the flurry of nationwide organizing that grew out of the Occupy Wall Street movement, student debt lies at the heart of contemporary debates over the future of U.S. higher education. According to researchers at the Federal Reserve Bank of New York, student loan debt is "the only form of consumer debt that has grown since the peak of consumer debt in 2008." Student loan debt now exceeds both credit card and auto loans, and represents "the largest form of consumer debt outside of mortgages." ${ }^{24}$ On one hand, it is possible to see scholarship athletes as inhabiting a world removed from the politics of student debt. The "full rides" that they receive distinguish them from their fellow students, who pay increasing amounts of tuition and interest every year. On the other hand, a closer examination of the Northwestern union campaign reveals that the specter of lifelong indebtedness looms just as large for scholarship athletes as it does for their classmates and contemporaries. 
For athletes, debt can take both financial and physical forms. As Colter told labor journalist Josh Eidelson, the long-term impact of injuries sustained in college was a primary impetus for the unionization drive at Northwestern. Colter noted that that medical coverage "extending past the end of a player's eligibility" and "concussion reform" constituted CAPA's top two priorities. Asked to elaborate on the personal experiences that had spurred his activism, Colter cited the physical toll that football had taken on his young body. "Now that I'm finished, I can, you know, feel the effects of some injuries that I've had throughout my time playing football. And you know, not knowing if I need to get those fixed down the road or taken care of, or if it's going to prevent me from working later on. Not having those medical protections guaranteed is a scary thing." 25 The unionization movement, with its core focus on players' long-term health concerns and the struggle against student debt, can be seen as twin expressions of student dissent from the ways in which the U.S. university system positions its graduates in the political economy of postcampus life.

The expanding business of college sports is hardly an incidental or peripheral part of the modern U.S. university. On the contrary, high-profile collegiate sports programs, particularly men's basketball and football, represent signal elements of the neoliberal turn on campus. ${ }^{26}$ Murray Sperber has argued that investments in sports have been central to the rise of funding and curricular changes that have sacrificed the quality of undergraduate education. "In a period when most institutions of higher education had many more places in their undergraduate classes than students to fill them, and schools desperately needed to increase the flow of tuition dollars, they marketed themselves in every way possible, many emphasizing their big-time sports programs and party atmosphere, usually depicted as "collegiate good times.",27

The changes that Sperber identifies coincide with what Christopher Newfield argues has been a radical assault on U.S. universities' once-heralded role in expanding access and opportunity to underrepresented minorities and workingclass students. The radical expansion of tuition costs is part of the evisceration of public investment in higher education by transferring the burden onto private sources of revenue, including individual students and their families. According to Newfield, "as cost pressures increased in the 1970s and 1980s, throughout this period admissions practice evolved toward the money." Significantly, Newfield cites the recruitment of athletes and "legacies" (the children of wealthy alumni) as central elements of admissions practices aimed at maximizing campuses' return on investment. ${ }^{28}$ Considered in this context, the politics of athletic labor and the politics of student debt stand together at the heart of the contested reconfiguration of U.S. higher education in the age of neoliberalism.

A key faculty ally of the student debt movement, Andrew Ross of New York University, offers a powerful analysis of the profound effects of student debt. "Many students are now compelled to seek out low-paying jobs to stay in college and stave off further debt; they are encouraged to think of their degrees as transactions in which their future wages have been traded; and they 
are increasingly directed toward fields of study that provide 'value' through the earning potential to repay their loans. These are not the conditions under which an agile critical mind is likely to be cultivated, but they are perfectly serviceable to elites who do not want an educated and active, freethinking citizenry on their hands. ${ }^{29}$ Resonances with this dimension of the student debt crisis have emerged throughout the recent upsurge of player militancy and the Northwestern case in particular. At the NLRB hearing, Colter explained that he had entered college planning to pursue a pre-med academic track but was quickly derailed from his plans because of pressure exerted by football coaches and academic advisers. As Ohr highlighted in his finding in favor of CAPA, Colter ultimately "decided to switch his major to psychology which he believed to be less demanding. ${ }^{\prime 30} \mathrm{Ohr}$ cited this aspect of Colter's collegiate career as evidence of the control that football coaches and other team staff exert over player's schedules and daily lives. When considered against the backdrop of the student debt movement, Colter's experience - and with it the impetus for the Northwestern unionization movement - articulates a broader problem endemic to modern undergraduate education. Colter, like millions of other students, found his educational aspirations constrained by his accumulating economic obligations to his college.

\section{The Struggle at the University of Missouri}

Among the most unmistakable characteristics of the corporatization of universities in recent years has been the growing cadre of campus leaders plucked from the business world. While U.S. universities have always cultivated connections with corporations, the hegemony of growth strategies and personnel policies based on corporate models is a relatively recent development, particularly at public research universities. In recent decades, however, such institutions' foundational commitments to advancing the "public good" have increasingly taken a backseat to securing the bottom line in the name of budget austerity. The recent history of leadership changes in the University of Missouri system, which includes the state's flagship campus at Columbia, along with campuses in Rolla, Kansas City, and St. Louis, is emblematic of the larger national trend toward a corporate approach to the management of U.S. higher education. The campus struggle that brought worldwide attention to rampant racism at the University of Missouri-Columbia in fall 2015 was, among other things, an indictment of the corporate approach to campus leadership embodied by Tim Wolfe, president of the University of Missouri system. A former software executive, Wolfe had begun his term as president in February 2012. Wolfe took over for Gary Forsee, himself a former corporate leader, having previously served as the chief executive of Sprint Nextel. Missouri was not the only site of campus resistance to corporate leadership in fall 2015. As Wolfe's ouster unfolded, the new president of the University of Iowa, Bruce Herreld, who had 
come to academia after an executive career with such companies as Boston Chicken and IBM, faced a censure vote from his faculty. ${ }^{31}$

From the start, Wolfe's presidency had been marked by controversy and discord, as his policies elicited pushback from students, staff, and faculty. In the first months of his presidency, Wolfe eliminated the subsidy to the University of Missouri Press, enraging many on campus and beyond. Staff members, concerned faculty and students, and observers across the country were dismayed not only at the prospect of a beloved intellectual institution being sacrificed in the name of the bottom line, but also at the process by which Wolfe had taken action, which did not include consultation with the press's employees. ${ }^{32}$ Press supporters in Missouri and beyond mobilized throughout spring and summer 2012 and ultimately succeeded in saving the institution from closure. ${ }^{33}$ The battle over the university's publishing house drew academia's attention to Wolfe as an embodiment of corporate governance. The rest of his presidency would cement that perception.

A series of events in fall 2015 brought simmering tensions to a boil, uniting a broad campus coalition in opposition to Wolfe's administration. One dimension of the dissent centered on the university's decimation of reproductive health services. Bowing to political pressure, in September 2015, the University of Missouri announced it would strip hospital privileges from a Planned Parenthood-affiliated physician, effectively depriving the clinic - the only one of its kind in the region-from providing abortion services. This decision came days after campus officials announced that Missouri students would no longer be permitted to train at Planned Parenthood as part of any academic program. ${ }^{34}$ Another dynamic feeding into the campus revolt in Columbia included an emerging graduate student unionization movement, sparked by university administrators' cancellation of health coverage for graduate students, a policy change that was reversed because of substantial organizing during the fall semester. $^{35}$

As the fall semester continued, the mobilization around Planned Parenthood and the nascent graduate student campaign were joined by an even more powerful movement on campus, inspired by a growing militancy among black students in the aftermath of the struggle in Ferguson, Missouri and amid the ongoing Black Lives Matter movement. African American students and their allies announced in the early weeks of the fall 2015 semester that business as usual was over. Columbia became a central location in the Black Lives Matter movement in response to an escalation of racial intimidation aimed at black students. On September 12, Payton Head, president of the Missouri Students Association, reported in a Facebook post that he had been the subject of repeated racial slurs. "Some guys in the back of a pickup just started yelling the 'N-word" at me," Head later told the campus newspaper. ${ }^{36}$ This wasn't the first time- -he had experienced a similar incident the previous semester. His decision to speak out on social media about the latest incident helped launch a new phase of the movement for racial justice on campus. 
Black students and allies organized two rallies - on September 24 and October 1 - under the slogan "Racism Lives Here," highlighting the depth of racism on campus and calling on campus administrators to act. Three days later, a white student harassed and directed a racial slur at members of an African American campus organization, the Legion of Black Collegians. In response to this latest incident, the university's chancellor ordered "Diversity and Inclusion" training for all faculty and staff, a measure greeted by student leaders as insufficient progress. The movement continued to grow. On October 10, student activists staged a protest at the homecoming parade, blocking university president Wolfe's car. Wolfe refused to engage with the students, and the protest culminated in police surrounding his vehicle, which at one point made contact with one of the protesters, graduate student Jonathan Butler. The students came away from the homecoming action with clear evidence that their university's president did not take their concerns seriously. As Head later described, "[Wolfe] laughed. In our faces. This is your president. This is America. 2015." "37

Ten days later, Concerned Student 1950, the organization that had organized the homecoming protest (named for the first year black students were admitted to the university) issued a list of eight demands. The demands included the removal of Wolfe, an increase in black faculty and staff, the adoption of a "comprehensive racial awareness and inclusion curriculum," a new strategic plan to retain marginalized students, and increased funding for campus mental health services and social justice centers. ${ }^{38}$ Though Wolfe eventually met with members of Concerned Student 1950, he refused their demands. That same week, a swastika smeared from human feces had appeared on a campus building, marking a further escalation of racial hostility. On November 2, Butler began a hunger strike. The next day, students began a boycott in support of Butler. On November 6, with growing national attention focused on the events taking shape in Columbia, Wolfe issued an apology to Concerned Student 1950 for his failure to engage the activists at the homecoming parade. ${ }^{39}$

Hours before Wolfe's overdue apology, the University of Missouri football team had hosted Mississippi State, losing 31-13 on a rainy Thursday night. ${ }^{40}$ That Saturday, a group of approximately thirty members of the team met with Butler, now in day six of his hunger strike. This meeting came after Butler had received visits in previous days by a small number of current and former players. Butler's visitors had included Michael Sam, the Mizzou defensive star who in 2014 became the first openly gay player selected in the National Football League draft. After hearing Butler describe the racism and systematic mistreatment that had driven him to go on a hunger strike, the football players pledged that they would support him by staging a walkout. ${ }^{41}$ After the group informed head coach Gary Pinkel of their plans, sophomore safety Anthony Sherrils tweeted a statement from fellow black players calling for change on their campus: "The athletes of color on the University of Missouri football team truly believe 'Injustice Anywhere is a threat to Justice Everywhere.' We will no longer participate in any football related activities until President Tim Wolfe 
resigns or is removed due to his negligence toward marginalized students' experiences. WE ARE UNITED!!!!!"42 Several other team members followed Sherrils's tweet with messages of their own.

The next day, Pinkel expressed his support for the players' stand, tweeting a photo of the entire team, accompanied by the message: "The Mizzou Family stands as one. We are united. We are behind our players. \#ConcernedStudent1950." Furthermore, the school's athletic department went on to issue a press release by Pinkel and university athletic director Mack Rhoades stating that the team would not hold any formal team activities. "Our focus right now is on the health of Butler, the concerns of our student-athletes and working with our community to address this serious issue." ${ }^{43}$ Pinkel's expression of support for his players' militant action took many observers and commentators by surprise. As the prominent progressive sports journalist Dave Zirin noted in the early hours of the players' stand, an earlier wave of militancy by African American college football players (in the late 1960s and early 1970s) had focused largely on the removal and replacement of racist coaches. ${ }^{44}$ Pinkel later distanced himself from the larger campus movement, suggesting that the assistant handling his Twitter account had mistakenly included \#ConcernedStudent 1950 in his now-famous tweet. "It was just about a young man that was really struggling." ${ }^{45}$ Nonetheless, Pinkel's support for the action, and the unity within the football program and athletic department that it seemed to articulate, helped to spell the end of Wolfe's career. The following day, Monday, November 9, marked a new stage of militancy in the campus movement. Professors describing themselves as "concerned faculty of the University of Missouri" walked out, joining graduate employees in a coordinated action expressing solidarity with Butler and other student activists. At 10 a.m., Wolfe announced his resignation in a hastily called press conference. Hours later, university chancellor R. Bowen Loftin resigned as well. ${ }^{46}$

In the immediate aftermath of Wolfe's announcement, it was clear that the football players' threat of a strike had been a decisive factor. As several observers were quick to point out, the football team's stand in support of Butler's hunger strike raised the financial stakes for Wolfe and his fellow administrators. Forfeiting the upcoming game against Brigham Young University would result in a $\$ 1$ million fine for breach of contract. That financial pressure, combined with a growing consensus in Missouri's statehouse that Wolfe could no longer effectively lead, left no other option besides resignation. ${ }^{47}$ Within weeks of Wolfe's departure, two Republican members of the Missouri House of Representatives introduced a bill aimed at curtailing the labor power of college athletes. "Any college athlete who calls, incites, supports, or participates in any strike or concerted refusal to play a scheduled game shall have his or her scholarship revoked," the proposed legislation declared. The bill also called for fines for any coach who "encourages or enables" such activity. The bill's sponsors withdrew the legislation in the wake of a significant public outcry. ${ }^{48}$ This brief legislative skirmish demonstrated the powerful reverberations of the 
players' actions and suggested that the struggle over the labor rights of college athletes - in Missouri and beyond - was far from over.

The battle over Tim Wolfe's tenure at the University of Missouri was one of dozens of campus struggles that unfolded in 2015, as students of color and their allies demanded institutional change on campus and beyond. While each campus's movement emerged from specific local circumstances, many articulated similar demands and highlighted a shared vision of change. Among the most common demands on campuses across North America were calls for more faculty of color, expanded curricula and campus programming devoted to study of race and racism, and increased support for student services devoted to minority and underserved student populations. ${ }^{49}$ On many campuses, the neoliberal transformation of U.S. higher education has been marked by disinvestment in departments, centers, and programs devoted to the study of race and ethnicity, even as administrators express support for the abstract values of multiculturalism and diversity. The recent upsurge in campus organizing, of which the Missouri struggle is a key part, represents one of the most significant developments in campus-based social movements since the campaigns of the 1960s and 1970s that first established ethnic studies programs and other campus commitments now under attack.

The Missouri movement highlights the special position that black athletes occupy in the racial configuration of the modern U.S. university. Citing NCAA data, Shaun R. Harper, executive director of the University of Pennsylvania's Center for the Study of Race and Equity in Education, notes that African American men represented just 3.3\% of undergraduates enrolled at the University of Missouri during the 2014-15 academic year. That same year, African Americans made up $65.3 \%$ of the university's football team. As Harper argues, the events in Columbia in fall 2015 demonstrated the "unique reputational and economic powers" that black athletes in revenue-generating sports have on their campuses.$^{50}$ It remains to be seen whether coalitions between athletes and other students will emerge on other campuses in the months and years to come. The Missouri movement's impact certainly suggests the potential power of such coalitions.

\section{Conclusion: Considering Football's Abolition}

College football has a growing chorus of detractors, both on campus and off. Generations of faculty, students, and observers have questioned the vast investment of resources that football requires, and whether such resources might be better allocated to other campus needs. Furthermore, growing attention to the lifelong consequences of brain injuries sustained by football players has fueled powerful arguments that the game compromises the publicly endowed mission of higher education. One prominent voice in this debate has been that of journalist Malcolm Gladwell. "Every single college in this country, rich or poor, big or small, is supported by . . taxpayer dollars," Gladwell noted in a 
2012 debate over the abolition of college football. "They are subsidized by us, they are given immunity from taxes, they are supported by laws of Congress, by acts of local legislatures. ... [They are] charged with a sacred trust, and that is to prepare the minds of young men and women to . . . to lead productive lives as full citizens of the United States. And nowhere, nowhere, in that social contract does it say that it's okay to promote and encourage young men to hit themselves over and over again in the head in the name of entertainment." 51

Gladwell is not the first to call for the abolition of college football. College campuses in the early years of the last century were home to raging debate over the sport's brutality and possible abolition. That debate led to reforms, and to the formation of a new body - the NCAA - that would further embed the sport within U.S. higher education. The outcome of the contemporary debate over college football's abolition stands as a major open question, the answer to which will do much to shape the future development of both the U.S. university system and the sports world. It is conceivable that the present era will mark the beginning of the end of college football. It is certain that it marks a watershed moment in the role of athletes in advocating - alongside other campus allies - for a transformation in the mission and governance of U.S. universities. The high-profile struggles at Northwestern and the University of Missouri have brought the experiences and perspectives of college football players to the foreground, profoundly shifting the debate over the relationship of the gridiron to the academy. Indeed, the most persuasive argument against abolition may be that football players have become indispensible contributors to the growing movement to transform the neoliberal university.

\section{Notes}

1. Taylor Branch, "The Shame of College Sports," The Atlantic, October 2011, http://www. theatlantic.com/magazine/archive/2011/10/the-shame-of-college-sports/308643/.

2. Ross Finkel, Trevor Martin, and Jonathan Paley, directors, Schooled: The Price of College Sports. Culver City, CA: Strand Releasing, 2013, DVD.

3. Joseph P. Williams, "Docs and Jocks: MDs, Coaches among States' Highest-Paid," US News and World Report, July 10, 2015, http://www.usnews.com/news/articles/2015/07/10/docsand-jocks-mds-coaches-among-states-highest-paid; Rachel Bachman, "ESPN Strikes Deal for College Football Playoff," Wall Street Journal, November 21, 2012, http://www.wsj.com/articles/SB1 0001424127887324851704578133223970790516.

4. Ben Strauss, "As Northwestern Players Pursue Unionization, a Voice in the Wilderness Gains a Chorus," New York Times, February 8, 2014, http:/www.nytimes.com/2014/02/09/sports/ ncaafootball/as-northwestern-players-pursue-unionization-voice-in-the-wilderness-gains-a-chorus.html? r=0.

5. National College Players Association (NCPA) website, accessed January 8, 2016, http:// www.ncpanow.org/.

6. Rohan Nadkarni, “Q\&A: Nick Dorzweiler, Former Teacher of Kain Colter,” Daily Northwestern, January 29, 2014, http://dailynorthwestern.com/2014/01/29/sports/qa-nick-dorzweilerformer-teacher-of-kain-colter/.

7. Rohan Nadkarni, "Kain Colter's Union Battle Cost Him More Than He Ever Expected," Deadspin.com, August 18, 2015, http://deadspin.com/kain-colters-union-battle-cost-him-morethan-he-ever-ex-1724831203.

8. Philip Rossman-Reich, "Kain Colter, Others Make Waves with Quiet Protest," Lake the Posts, September 25, 2013, http://www.laketheposts.com/2013/09/25/kain-colter-others-makewaves-with-quiet-protest/. See for a discussion of criticism published on social media.

9. Teddy Greenstein, "Colter on APU: It's 'Not Me versus Northwestern," Chicago Tribune, September 25, 2013, http://articles.chicagotribune.com/2013-09-25/sports/chi-kain-coter- 
says-of-the-all-players-united-movement-its-not-me-versus-northwestern-20130925_1_apu-nuplayers-football-players.

10. Nadkarni, "Kain Colter's Union Battle"; Tom Farrey, "Kain Colter Starts Union Movement," ESPN.com, January 28, 2014, http://abcnews.go.com/Sports/kain-colter-starts-unionmovement $/$ story? id=22264339.

11. Travis Waldron, "Michigan Legislature Set to Ban College Athletes from Unionizing," December 12, 2014, ThinkProgress.org, http://hinkprogress.org/sports/2014/12/12/3602837/michigan-ban-ncaa-athletes-unions-northwestern/.

12. Kain Colter, televised interview with Bob Ley, "Outside the Lines," ESPN, January 28, 2014, http://www.youtube.com/watch?v=Uw729k3AzVE.

13. Farrey, "Colter Starts Union Movement."

14. Northwestern University and College Athletes Players Association (CAPA), NLRB decision, case 13-RC-121359, 362 NLRB No. 167 (2015), 13-14. In his decision, Ohr noted that Northwestern had the burden of proof: "A party seeking to exclude an otherwise eligible employee from the coverage of the Act bears the burden of establishing a justification for the exclusion."

15. Brown University and International Union, United Automobile, Aerospace and Agricultural Implement Workers of America (UAW AFL-CIO), NLRB decision, case 1-RC-21368, 342 NLRB No. 42 (2004), 489. In August 2016, in a case involving graduate teachers at Columbia University, the NLRB reversed the Brown decision. See Colleen Flaherty, "NLRB: Graduate Students at Private Universities May Unionize," Inside Higher Ed, August 24, 2016, https://www.insidehighered.com/news/2016/08/24/nlrb-says-graduate-students-private-universities-may-unionize.

16. Northwestern, 14-18.

17. Lester Munson, "NLRB Decision Very Well-Reasoned," ESPN.com, April 11, 2014, http://espn.go.com/espn/otl/story/_/id/10678393/nlrb-director-decision-follows-road-map-laidnorthwestern-quarterback-kain-colter-legal-team.

18. Dan Wolken, "NCAA Board Approves Division I Autonomy Proposal," USA Today, August 7, 2014, http://www.usatoday.com/story/sports/college/2014/08/07/ncaa-board-of-directorsautonomy-vote-power-five-conferences/13716349/; Ron Clements and Joe Rodgers, "Power 5 NCAA Schools Pass New Scholarship, Concussion Proposals," Sporting News, January 17, 2015, http://www.sportingnews.com/ncaa-football-news/4632825-power-5-ncaa-schools-vote-newscholarship-concussion-proposals-autonomy.

19. Paul Myerberg, "NCAA Schools Put Money Where Athletes' Mouths Are," USA Today, April 26, 2015, http://www.usatoday.com/story/sports/college/2015/04/26/unlimited-food-snackswisconsin-oregon-ncaa-student-athletes/26405105/.

20. "Board Unanimously Decides to Decline Jurisdiction in Northwestern Case," National Labor Relations Board press release, August 17, 2015, https://www.nlrb.gov/news-outreach/newsstory/board-unanimously-decides-decline-jurisdiction-northwestern-case.

21. Tom Farrey, "Northwestern Players Denied Request to Form First Union for Athletes," ESPN.com, August 17, 2015, http://abcnews.go.com/Sports/northwestern-players-denied-requestform-union-athletes/story?id=33135409.

22. Marc Bousquet, How the University Works: Higher Education and the Low-Wage Nation (New York: New York University Press, 2008).

23. "National Faculty Coalition Formed to Work with College Profit Athletes on Civil \& Human Rights Issues," College Athletes Rights and Empowerment Faculty Coalition press release, March 12, 2015, http://care-fc.org/wp-content/uploads/2015/03/CAREFacultyCoalitionPressReleaseEmbargoeduntilMarch122015.pdf.

24. "Student Loan Debt by Age Group," Federal Reserve Bank of New York, March 29, 2013, http://www.newyorkfed.org/studentloandebt/.

25. Josh Eidelson, "We're Not Little Kids!" Salon, April 1, 2014, http://www.salon. com/2014/04/01/we\%E2\%80\%99re_not_little_kids_northwestern_quarterback_kain_coulter_ sounds_off_on_ncaa_union_fight/.

26. Jeff Maskovsky, "Beyond Neoliberalism: Academia and Activism in a Nonhegemonic Moment," American Quarterly 64, no. 4 (December 2012): 819. According to Maskovsky, characteristics of the neoliberal turn on campus include "the advent of consumerist, market-driven learning; the privatization, corporatization, and branding of the university; the decline in public spending on higher education; the speed-up of the academic assembly line; audit culture; outcomes assessment and other efficiency-oriented interventions; and the casualization of academic labor."

27. Murray Sperber, Beer and Circus: How Big-Time College Sports Is Crippling Undergraduate Education (New York: Henry Holt, 2000), 52.

28. Christopher Newfield, Unmaking the Public University: The Forty-Year Assault on the Middle Class (Cambridge: Harvard University Press, 2011), 178.

29. Andrew Ross, "In Defense of Economic Disobedience," Occasion 7 (November 2014), 3.

30. Northwestern, 11.

31. Sharon Terlep and Douglas Belkin, "Mizzou Athletic Department Backs Black Football Players on Boycott," Wall Street Journal, November 8, 2015, http://www.wsj.com/articles/minority-players-on-university-of-missouri-football-team-threaten-boycott-1446997013. 
32. John Eligon, "Plan to Close University of Missouri Press Stirs Anger," New York Times, July 18, 2012, http://www.nytimes.com/2012/07/18/us/university-of-missouri-press-closing-incites-anger.html? $\mathrm{r}=0$.

33. Janese Silvey, "Press to Stay Open, Shift to MU Campus," Columbia Tribune, August 28, 2012, http:/www.columbiatribune.com/news/education/press-to-stay-open-shift-to-mu-campus/ article 49d527-d23c-5ac8-bb78-76e54c415708.html.

34. Jason Hancock, "University of Missouri Strips Privileges from Planned Parenthood Doctor," Kansas City Star, September 25, 2015, http://www.kansascity.com/news/local/news-columnsblogs/the-buzz/article36530685.html.

35. Megan Favignano, "MU Grad Students Collect More Than 1,000 Signatures Calling for Union Election," Columbia Tribune, December 18, 2015, http://www.columbiatribune.com/news/ education/mu-grad-students-collect-more-than-signatures-calling-for-union/article_5a3f5ce57d8e-53bb-a236-87936c05e409.html.

36. Ruth Severn, "MSA President Speaks Out about Racist Incident," The Missourian, September 14, 2015, http://www.columbiamissourian.com/news/higher education/msa-presidentspeaks-out-about-racist-incident/article_ac4eb2-5b3e-11e5-4d-a5513bae-45.html.

37. Michael Pearson, "A Timeline of the University of Missouri Protests," CNN.com, November 10, 2015, http:/www.cnn.com/2015/11/09/us/missouri-protest-timeline/.

38. "List of Demands from Concerned Student 1950 Group," Columbia Tribune, October 23, 2015, http://www.columbiatribune.com/list-of-demands-from-concerned-student-group/ pdf_345ad844-9f05-5479-9b64-43624155.html

39. Tyler Kingkade, "The Incident You Have to See to Understand Why Students Wanted Mizzou's President to Go," Huffington Post, November 10, 2015, http://www.huffingtonpost.com/ entry/tim-wolfe-homecoming-parade us 56402cc8e4b0307f2cadea10.

40. “Game Report: Mississippi State 31, Missouri 13,” Kansas City Star, November 6, 2015, http://www.kansascity.com/sports/college/sec/university-of-missouri/article43422447.html.

41. Elizabeth Merrill, "Timeline: How One Student Started a Protest, Stopped a Football Team and Rocked Missouri," ESPN.com, November 11, 2015, http://espn.go.com/blog/sec/post/_ I id/110270/timeline-how-one-student-started-a-protest-stopped-a-football-team-and-rocked-missouri.

42. Rohan Nadkarni and Alex Nieves, "Why Missouri’s Football Team Joined a Protest against School Administration," SI.com, November 9, 2015, http://www.si.com/college-football/2015/11/09/missouri-football-protest-racism-tim-wolfe.

43. Ibid.

44. Dave Zirin, "Edge of Sports," Twitter.com, https://witter.com/EdgeofSports/status/663187732886364160.

45. Gary Pinkel, interview with Kevin Kietzman, Sports Radio 810 WHB, November 11, 2015, http://www.infoblizzard.com/the-blog-smog/a-sports-radio-station-interviewed-gary-pinkelthis-morning-and-things-got-really-awkward.

46. Douglas Belkin and Melissa Korn, "University of Missouri System President Tim Wolfe Resigns," Wall Street Journal, November 9, 2015, http://www.wsj.com/articles/university-of-missouri-system-president-tim-wolfe-resigns-1447086505.

47. Michael E. Miller, "With \$1 Million at Stake, U. of Missouri’s President Now Taking Protests Seriously," Washington Post, November 9, 2015, https://www.washingtonpost.com/news/ morning-mix/wp/2015/11/09/with-1-million-at-stake-u-of-missouris-president-now-taking-protests-seriously/. On Sunday, November 9, Representative Steve Cookson, the Republican chair of the Missouri House Committee on Higher Education, told ia reorter, "It has become clear that the MU system leadership can no longer effectively lead and should step aside."

48. Dave Helling and Tod Palmer, "Missouri Lawmakers Want Scholarships Revoked If College Athletes Go on Strike, Kansas City Star, December 14, 2015, http://www.kansascity.com/ news/local/news-columns-blogs/the-buzz/article49686940.html\#storylink=cpy; A.J. Perez, "Missouri Legislator Withdraws Bill to Bar Student-Athletes from Protests," USA Today, December 16, 2015, http:/www.usatoday.com/story/sports/college/2015/12/16/missouri-legislator-rick-brattinwithdraws-bill-bar-student-athlete-protests/77417410/.

49. A growing compilation of student demands is available at www.thedemands.org.

50. Shaun R. Harper, "Black College Football and Basketball Players Are the Most Powerful People of Color on Campus," Washington Post, November 11, 2005, https:/www.washingtonpost. $\mathrm{com} /$ posteverything/wp/2015/11/11/black-college-football-and-basketball-players-are-the-mostpowerful-people-of-color-on-campus/.

51. Intelligence Squared U.S., "Ban College Football,” debate transcript, May 8, 2012, http:// intelligencesquaredus.org/images/debates/past/transcripts/ban-college-football.pdf. 